\title{
TRPM8 Activation by Menthol, Icilin, and Cold Is Differentially Modulated by Intracellular $\mathrm{pH}$
}

\author{
David A. Andersson, Henry W. N. Chase, and Stuart Bevan \\ Novartis Institute for Medical Sciences, London WC1E 6BN, United Kingdom
}

\begin{abstract}
TRPM8 is a nonselective cation channel activated by cold and the cooling compounds menthol and icilin (Peier et al., 2002). Here, we have used electrophysiology and the calcium-sensitive dye Fura-2 to study the effect of $\mathrm{pH}$ and interactions between temperature, $\mathrm{pH}$, and the two chemical agonists menthol and icilin on TRPM8 expressed in Chinese hamster ovary cells. Menthol, icilin, and cold all evoked stimulus-dependent $\left[\mathrm{Ca}^{2+}\right]_{\mathrm{i}}$ responses in standard physiological solutions of $\mathrm{pH}$ 7.3. Increasing the extracellular $\left[\mathrm{H}^{+}\right]$from $\mathrm{pH} 7.3$ to approximately $\mathrm{pH} 6$ abolished responses to icilin and cold stimulation but did not affect responses to menthol. Icilin concentrationresponse curves were significantly shifted to the right when $\mathrm{pH}$ was lowered from 7.3 to 6.9 , whereas those with menthol were unaltered in solutions of $\mathrm{pH}$ 6.1. When cells were exposed to solutions in the range of $\mathrm{pH}$ 8.1-6.5, the temperature threshold for activation was elevated at higher $\mathrm{pH}$ and depressed at lower $\mathrm{pH}$. Superfusing cells with a low subactivating concentration of icilin or menthol elevated the threshold for cold activation at $\mathrm{pH}$ 7.4, but cooling failed to evoke $\left[\mathrm{Ca}^{2+}\right]_{\mathrm{i}}$ responses at $\mathrm{pH} 6$ in the presence of either agonist. In voltage-clamp experiments in which the intracellular $\mathrm{pH}$ was buffered to different levels, acidification reduced the current amplitude of icilin responses and shifted the threshold for cold activation to lower values with half-maximal inhibition at pH 7.2 and pH 7.6.

The results demonstrate that the activation of TRPM 8 by icilin and cold, but not menthol, is modulated by intracellular pH in the physiological range. Furthermore, our data suggest that activation by icilin and cold involve a different mechanism to activation by menthol.
\end{abstract}

Key words: temperature; pain; sensory neurons; menthol; TRP channels; pH

\section{Introduction}

The transient receptor potential (TRP) channel TRPM8 is a $\mathrm{Ca}^{2+}$-permeable nonselective cation channel activated by cold and the cooling compounds menthol and icilin (Tsavaler et al., 2001; McKemy et al., 2002; Peier et al., 2002). TRPM8 is expressed in the small DRG neurons and in neurons from trigeminal ganglia (McKemy et al., 2002; Peier et al., 2002). In mouse DRG neurons in vivo, TRPM8 is not colocalized with either TRPV1, IB4 binding, or CGRP (Peier et al., 2002), whereas a proportion of TRPV1-positive DRG neurons in culture express TRPM8 (Reid et al., 2002; Story et al., 2003). This pattern of expression, in small unmyelinated cells distinct from polymodal nociceptors, is consistent with a role in thermosensation and nociception (noxious cold). Furthermore, the activation threshold of TRPM8 is similar to the reported threshold for noxious cold in human tissues (Klement and Arndt, 1992). Although TRPM8 is a prime candidate to detect cold and noxious cold stimulus, not all cold-responsive peripheral neurons express TRPM8 (Nealen et al., 2003; Story et al., 2003). Indeed, a novel TRP channel (ANKTM1 or TRPA1) is expressed in a population of DRG neurons that lack TRPM8 and is activated by cold (Story et al., 2003). Another ion channel that has been suggested to act as

Received March 11, 2004; revised April 23, 2004; accepted April 30, 2004.

We thank Illaria Dragoni and Peter McIntyre for the TRPM8 cell line and for valuable discussions.

Correspondence should be addressed to Dr. David Andersson, Novartis Institute for Medical Sciences, 5 Gower

Place, London WC1E 6BS, UK. E-mail: David.Andersson@pharma.novartis.com.

D0I:10.1523/JNEUROSCI.0890-04.2004

Copyright $\odot 2004$ Society for Neuroscience $\quad$ 0270-6474/04/245364-06\$15.00/0 a cold receptor is TREK-1, a twin-pore domain potassium channel that is inhibited by cold (Maingret et al., 2000).

Studies on the thermosensitive TRPV1 channel have illustrated the importance of external $\mathrm{pH}\left(\mathrm{pH}_{\mathrm{o}}\right)$ on channel function. Changes in the $\mathrm{pH}$ in the (patho)physiological range can modulate the ability of capsaicin to activate TRPV1 (Kress et al., 1996; Tominaga et al., 1998; McLatchie and Bevan, 2001). Acidification to $\mathrm{pH}$ $<6.5$ can also activate TRPV1 at room temperature by lowering the thermal threshold for activation (Tominaga et al., 1998).

In this study, we investigated the effects of $\mathrm{pH}$ on the activation of TRPM8 induced by two chemical mediators, menthol and icilin, and by cold. Our results demonstrate that $\mathrm{pH}$ has a differential effect on TRPM8 activation and that the modulatory effect is determined by intracellular $\mathrm{pH}\left(\mathrm{pH}_{\mathrm{i}}\right)$. Acidic $\mathrm{pH}$ inhibits responses to icilin and cold, whereas alkaline $\mathrm{pH}$ has a potentiating effect. In contrast, menthol responses are not affected by $\mathrm{pH}$, suggesting that activation by icilin and cold involve a different mechanism to activation by menthol.

\section{Materials and Methods}

Cell culture. Chinese hamster ovary $(\mathrm{CHO})$ cells expressing mouse TRPM8 (generated as described by Peier et al., 2002) were grown in MEM $\alpha$ medium, without ribonucleosides and deoxyribonucleosides, supplemented with penicillin $(100 \mathrm{U} / \mathrm{ml})$, streptomycin $(100 \mu \mathrm{g} / \mathrm{ml})$, L-glutamine (2 mM), FCS (10\%), and hygromycin B $(200 \mu \mathrm{g} / \mathrm{ml})$.

Imaging of intracellular calcium levels. To study intracellular calcium $\left(\left[\mathrm{Ca}^{2+}\right]_{\mathrm{i}}\right)$ levels in a population of cells, fluorescence was measured using a Flexstation (Molecular Devices, Sunnyvale, CA). Cells were plated in black 96-well plates (Corning, Corning, NY), at an approximate density of 30,000 cells/well and grown overnight. Cells were loaded for $\sim 1 \mathrm{hr}$ with $2 \mu \mathrm{M}$ Fura-2 AM (Molecular Probes, Leiden, The Netherlands) in 
A

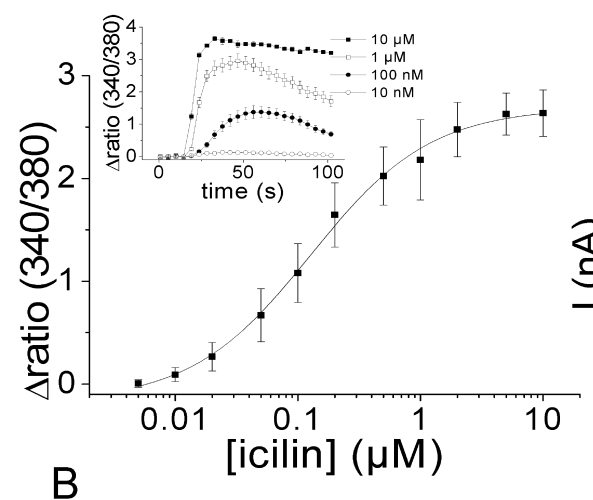

D

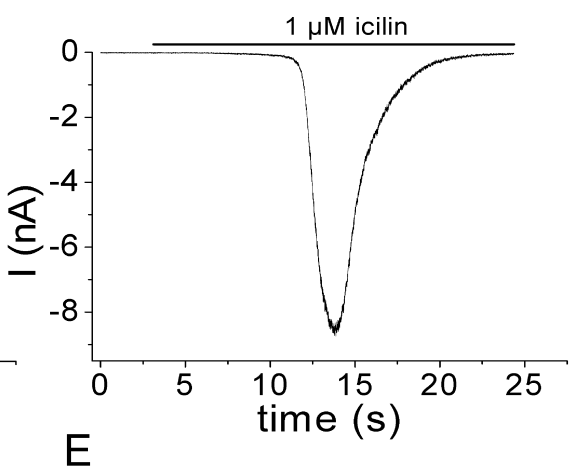

$\mathrm{E}$

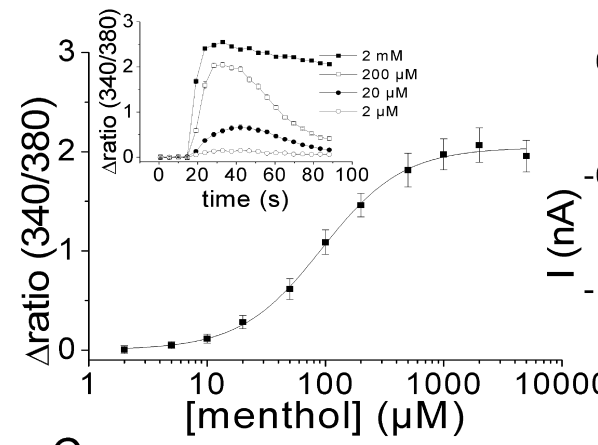

C $35^{\circ} \mathrm{C}$
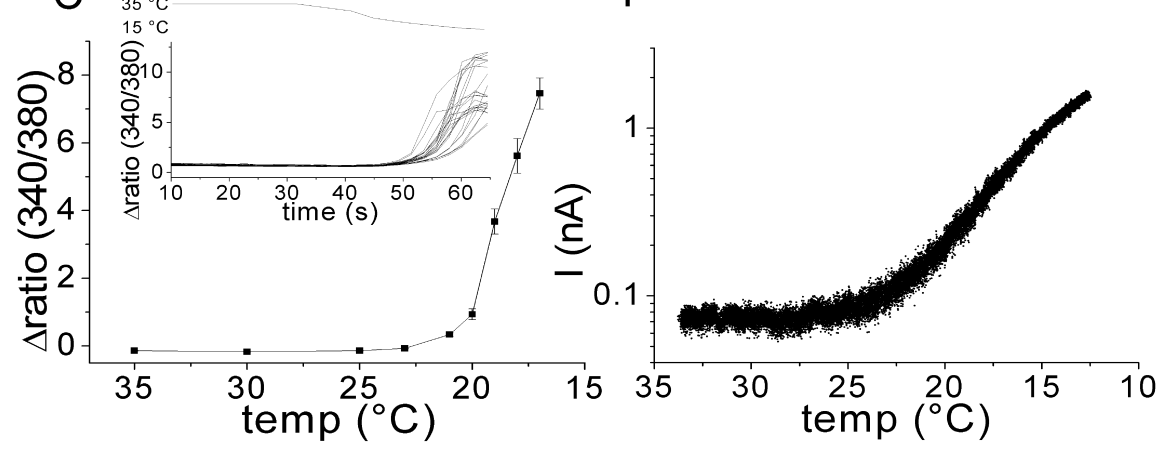

Figure 1. Icilin, menthol, and cold evoke $\left[\mathrm{Ca}^{2+}\right]_{\mathrm{i}}$ responses and currents at pH 7.3. Concentration-response curves for icilin $(A)$ and menthol $(B)$ in TRPM8-expressing CHO cells. Data points represent mean maximal $\left[\mathrm{Ca}^{2+}\right]_{\mathrm{i}}$ response produced by each drug concentration during a $60 \mathrm{sec}$ application, as illustrated in the insets (baseline ratios before the addition of drug has been subtracted; menthol, $n=11$; icilin, $n=7$ ). Drug was added after $17 \mathrm{sec}$. C, Cells exposed to a temperature ramp from 37 to $17^{\circ} \mathrm{C}$ were activated $\sim 22^{\circ} \mathrm{C}$ (average response in 25 cells). The individual responses in the same 25 cells are shown in the inset. Icilin (1 $\mu \mathrm{M})$ and menthol $(1 \mathrm{~mm})$ evoked large inward currents $(D, E)$. Currents in response to both agonists developed rapidly, but for icilin always after a short initial delay (at a holding potential of $-60 \mathrm{mV}$ ). Icilin-evoked currents desensitized completely, whereas the desensitization of currents evoked by menthol varied. $F$, Current-temperature relationship in a cell exposed to a temperature ramp (at a holding potential of $+60 \mathrm{mV}$ ). This particular cell had a threshold close to $24^{\circ} \mathrm{C}$ and a $\mathrm{Q}_{10}$ of 35 (in the temperature range from 20 to $\left.15^{\circ} \mathrm{C}\right)$.

the presence of $2 \mathrm{~mm}$ probenecid and $0.01 \%$ pluronic $\mathrm{F}-127$ at $37^{\circ} \mathrm{C}$. Loading and experiments were performed in an assay buffer containing (in mM) $140 \mathrm{NaCl}, 5 \mathrm{KCl}, 10$ glucose, 10 HEPES (replaced with $5 \mathrm{~mm}$ HEPES and $5 \mathrm{~mm}$ MES in experiments in which $\mathrm{pH}$ was $6.5-6.9$, by 10 mM MES below $\mathrm{pH}$ 6.5, and by $10 \mathrm{~mm} N$-(1,1-dimethyl-2-hydroxyethyl)3-amino-2-hydroxypropanesulfonic acid (AMPSO) above $\mathrm{pH} 7.7), 2$ $\mathrm{CaCl}_{2}$, and $1 \mathrm{MgCl}_{2}$, buffered to $\mathrm{pH} 7.4(\mathrm{NaOH})$ at $24^{\circ} \mathrm{C}$. Emission intensity was measured for $90 \mathrm{sec}$, every 4 or $5 \mathrm{sec}$ using excitation wavelengths of 340 and $380 \mathrm{~nm}$ and an emission of $520 \mathrm{~nm}$. Drugs were added after $17 \mathrm{sec}$. In other experiments, the $\left[\mathrm{Ca}^{2+}\right]_{\mathrm{i}}$ in groups of individual cells was monitored using a microscope-based system as described previously (Savidge et al., 2001). Cells were grown on glass coverslips covered with poly-D-lysine and loaded with Fura- 2 as described above and then placed in a laminar flow perfusion chamber. Temperature and $\mathrm{pH}_{\mathrm{o}}$ were changed by local microperfusion of solution through a fine pipette positioned very close to the cells being studied. The temperature of the perfusion buffer was controlled by a regulated Peltier device (Marlow Industries, Dallas, TX) and monitored by a thermocouple positioned in the tip of the pipette. Images of a group of cells were captured every $2 \mathrm{sec}$ at 340 and $380 \mathrm{~nm}$ excitation wavelengths with emission measured at $520 \mathrm{~nm}$ with an imaging system (PTI, South Brunswick, NJ). Analyses of emission intensity ratios at $340 \mathrm{~nm} / 380 \mathrm{~nm}$ excitation ( $\mathrm{R}$, in individual cells) were performed with the ImageMaster suite of software.

Measurements of $\mathrm{pH}_{i}$. Changes in $\mathrm{pH}_{\mathrm{i}}$ were measured using a Flexstation (Molecular Devices). Cells were prepared in the same way as described above for measuring $\left[\mathrm{Ca}^{2+}\right]_{\mathrm{i}}$ and then loaded for $\sim 1$ hr with $2 \mu \mathrm{M} 2^{\prime}, 7^{\prime}$-bis-(2carboxyethyl)-5-(and 6)-carboxyfluorescein (BCECF) acetoxymethyl ester in the presence of $2 \mathrm{~mm}$ probenecid and $0.01 \%$ pluronic F-127 at $37^{\circ} \mathrm{C}$. Emission intensity was measured every 5 sec using excitation wavelengths of 440 and 490 $\mathrm{nm}$ and an emission of $535 \mathrm{~nm}$. A standard curve of $\mathrm{pH}_{\mathrm{i}}$ was constructed in the presence of $20 \mu \mathrm{M}$ nigericin in a buffer prepared as above, except for an equimolar substitution of $110 \mathrm{~mm}$ $\mathrm{NaCl}$ by $\mathrm{KCl}$. To change $\mathrm{pH}_{\mathrm{o}}$, cells were kept in a weakly buffered solution (1 mM HEPES, pH 7.3), and after $22 \mathrm{sec}$ solution (three times the volume present in the well; buffered with $10 \mathrm{mM}$ HEPES or MES) was added to reach the desired $\mathrm{pH}$. The final $\mathrm{pH}$ of the solutions was determined in parallel experiments by direct measurement.

Electrophysiology. $\mathrm{CHO}$ cells expressing TRPM8 grown on glass coverslips covered with poly-Dlysine were studied by whole-cell voltage-clamp recordings using an Axopatch 200A amplifier filtered at $5 \mathrm{kHz}$ and pClamp 8.0 software (Axon Instruments, Union City, CA). Experiments were performed at a holding potential of $-60 \mathrm{mV}$, unless stated otherwise. Borosilicate glass pipettes (2-5 M $\Omega$ ) were filled with (in mM) $140 \mathrm{KCl}, 0.05 \mathrm{CaCl}_{2}, 1 \mathrm{MgATP}, 0.1 \mathrm{EGTA}$, and 10 HEPES (replaced with $5 \mathrm{mM}$ HEPES and $5 \mathrm{~mm}$ MES in experiments in which $\mathrm{pH}$ was 6.5-6.9 and by $10 \mathrm{~mm}$ AMPSO above $\mathrm{pH} 7.7$ ), $\mathrm{pH} 7.4(\mathrm{KOH})$. Extracellular solutions contained (in mM) $100 \mathrm{NaCl}, 80$ sucrose, $5 \mathrm{KCl}, 10$ HEPES (replaced with $5 \mathrm{~mm}$ HEPES and $5 \mathrm{~mm}$ MES in experiments in which $\mathrm{pH}$ was 6.5-6.9, by $10 \mathrm{~mm}$ MES below $\mathrm{pH} 6.5$, and by $10 \mathrm{~mm}$ AMPSO above $\mathrm{pH}$ 7.7), 10 glucose, and 1 $\mathrm{CaCl}_{2}$. The cells were superfused locally through a thin tube positioned very close to the cells. The temperature was controlled as described above for $\left[\mathrm{Ca}^{2+}\right]_{i}$ measurements. In experiments in which $\mathrm{pH}_{\mathrm{i}}$ was studied, the cells were left to equilibrate for $\sim 3 \mathrm{~min}$ before recording.

Drugs. (-) Menthol was from Sigma (St. Louis, MO), and icilin was from Tocris Cookson (Bristol, UK).

Calculation and statistics. Data are presented as means \pm SEM for the number of experiments indicated $(n)$. Curve fitting was performed in Origin 7 (Originlab, Northampton, MA). Statistical significance was calculated using an unpaired $t$ test or ANOVA, followed by Bonferroni's post hoc test.

\section{Results}

We used the calcium-sensitive dye Fura-2 and whole-cell voltageclamp recordings to investigate the effects of $\mathrm{pH}$ on the activity of 

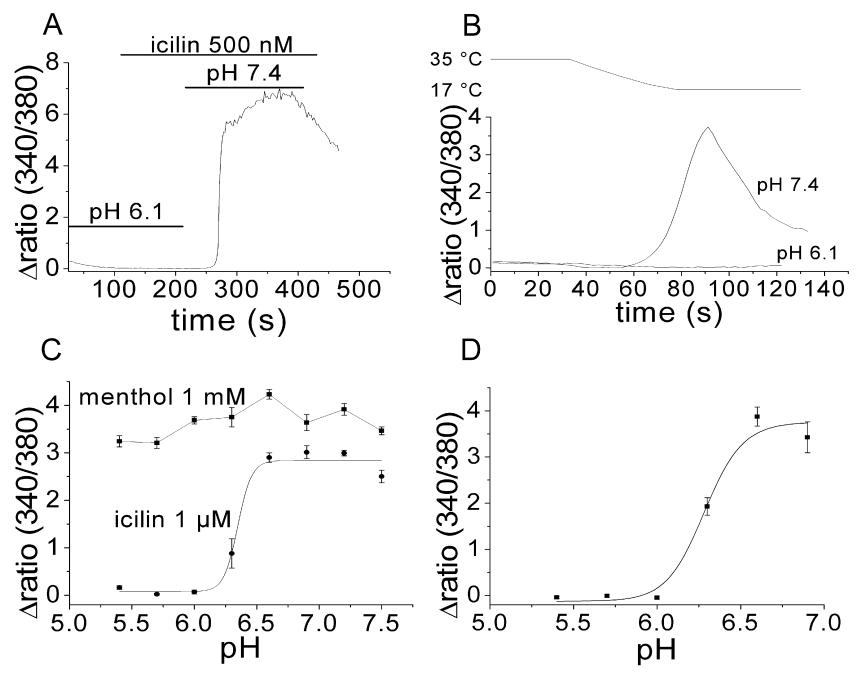

Figure 2. $\mathrm{LOW} \mathrm{pH}_{0}$ inhibits TRPM8 activation by cold and icilin but not menthol. $A$, Trace from a single cell, demonstrating that icilin is unable to evoke a response at $\mathrm{pH}_{0} 6.1$ but evokes a large $\left[\mathrm{Ca}^{2+}\right]_{\mathrm{i}}$ response when $\mathrm{pH}_{0}$ is restored to $\mathrm{pH} 7.4$ (experiment performed at $27^{\circ} \mathrm{C}$ ). $\mathrm{B}$, Cold stimulation (temperature ramp from 35 to $17^{\circ} \mathrm{C}$ ) evokes a $\left[\mathrm{Ca}^{2+}\right]_{\mathrm{i}}$ response at $\mathrm{pH}_{0} 7.4$ but not in solutions of $\mathrm{pH}_{0} 6.1$; data from single cells. $\mathrm{C}$, Low $\mathrm{pH}_{0}$ completely inhibits responses induced by $1 \mu \mathrm{m}$ icilin, whereas responses to $1 \mathrm{~mm}$ menthol are not significantly affected. Each data point is the mean response in six wells; similar results were obtained in three experiments. $D$, Low $\mathrm{pH}_{0}$ completely inhibits $\left[\mathrm{Ca}^{2+}\right]_{\mathrm{i}}$ responses induced by cold $\left(17^{\circ} \mathrm{C}\right)$. Data points are mean responses to $17^{\circ} \mathrm{C}$ in groups of cells monitored individually $(n=13-21)$.

TRPM8 heterologously expressed in CHO cells. Both icilin and menthol induced concentration-dependent $\left[\mathrm{Ca}^{2+}\right]_{\mathrm{i}}$ responses in Flexstation assays with estimated $\mathrm{EC}_{50}$ values of $125 \pm 30 \mathrm{nM}$ for icilin $(n=7)$ and $101 \pm 13 \mu \mathrm{M}$ for menthol $(n=11)$, in solutions of physiological pH 7.3 (Fig. 1A,B). To study temperatureinduced activation, we used an imaging system that allowed us to monitor the $\left[\mathrm{Ca}^{2+}\right]_{\mathrm{i}}$ levels in individual cells. Exposing cells to a cooling ramp induced $\left[\mathrm{Ca}^{2+}\right]_{\mathrm{i}}$ responses with an activation threshold of $22.6 \pm 0.7^{\circ} \mathrm{C}$ (an average of four determinations of groups of individual cells; $n=18-31$ ) (Fig. 1C). Menthol, icilin, and cold did not produce $\left[\mathrm{Ca}^{2+}\right]_{\mathrm{i}}$ responses in untransfected $\mathrm{CHO}$ cells (data not shown). In voltage-clamp experiments, all three stimuli evoked currents (Fig. $1 D-F$ ), but responses to icilin developed after a short lag period and desensitized rapidly and completely $(1 D)$. In contrast, menthol responses occurred with no obvious lag and showed a more varying degree of desensitiza-

A
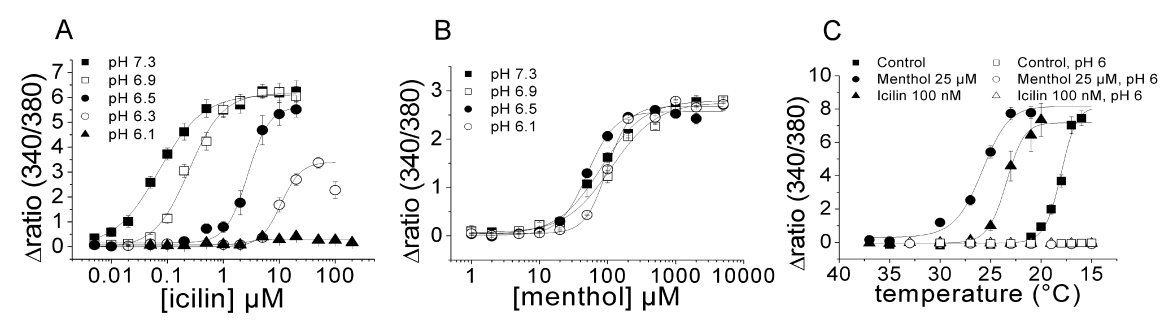

Figure 3. Effect of pH on concentration-response curves for icilin and menthol. A, Acidification of the extracellular solution caused a rightward shift of the responses to icilin, followed by insurmountable inhibition at lower $\mathrm{pH}_{0}$ (experiment shown is representative for $n=4) . B,\left[\mathrm{Ca}^{2+}\right]_{\mathrm{i}}$ responses evoked by menthol were not affected by acidification $\left(p>0.05\right.$ for $\mathrm{E}_{\max }$ and $\mathrm{pEC}_{50}$; one-way ANOVA; $\left.n=4\right)$. $C$, Effect of menthol and icilin on $\left[\mathrm{Ca}^{2+}\right]_{\mathrm{i}}$ responses induced by cold stimulation. Cells were superfused at $37^{\circ} \mathrm{C}$ with a solution of $\mathrm{pH}_{0} 7.3$ containing $25 \mu \mathrm{m}$ menthol, $100 \mathrm{~nm}$ icilin (agonist concentrations that did not produce $\left[\mathrm{Ca}^{2+}\right]_{\mathrm{i}}$ responses on their own at this temperature) or vehicle for $1 \mathrm{~min}$ before they were stimulated by a temperature ramp down to $15^{\circ} \mathrm{C}$. Responses to cold were significantly shifted to higher temperatures in the presence of either agonist ( $p<0.001 ; n=4$ for menthol and $n=5$ for icilin, in which each determination was the mean response of $n=21-31$ individual cells). When the same experiments were performed in solutions of $\mathrm{pH}_{0} 6, \mathrm{no}_{0}\left[\mathrm{Ca}^{2+}\right]_{\mathrm{i}}$ response developed in the absence or presence of either agonist $(n=4)$. tion. In some cells, responses to menthol desensitized very little, but in other cells the currents desensitized almost entirely within 5-10 sec (Fig. 1E). Because icilin (but not menthol) requires the presence of extracellular $\mathrm{Ca}^{2+}$ to activate TRPM8 (McKemy et al., 2002), we could not use $\mathrm{Ca}^{2+}$-free solutions to minimize $\mathrm{Ca}^{2+}$-dependent desensitization.

\section{Effects of $\mathrm{pH}_{\mathrm{o}}$ on $\left[\mathrm{Ca}^{2+}\right]_{\mathrm{i}}$ responses evoked by icilin, menthol,}

Changing the extracellular $\mathrm{pH}$ to values in the range 5.4-7.4 did not elicit $\left[\mathrm{Ca}^{2+}\right]_{\mathrm{i}}$ responses in the absence of other stimuli (data not shown). We next tested whether acidification of the external solution could affect $\left[\mathrm{Ca}^{2+}\right]_{\mathrm{i}}$ responses induced by a single concentration of agonist ( $1 \mu \mathrm{M}$ icilin or $1 \mathrm{~mm}$ menthol) or by a temperature stimulus of $17^{\circ} \mathrm{C}$ (the temperature of the superfusate was ramped from $35^{\circ} \mathrm{C}$ to $17^{\circ} \mathrm{C}$ ) (Fig. 2). These stimuli were chosen because they could be expected to evoke large responses. In solutions of $\mathrm{pH}_{\mathrm{o}} 6$ or below, icilin and cold no longer induced $\left[\mathrm{Ca}^{2+}\right]_{\mathrm{i}}$ responses (Fig. $2 \mathrm{~A}, \mathrm{~B}$ ). $\mathrm{pH}_{\mathrm{o}}$-response curves showed that protons inhibited both cold and icilin with a $\mathrm{pIC}_{50}$ value of $\mathrm{pH}$ $6.3 \pm 0.1$ (Fig. $2 C, D$ ). In contrast, $\left[\mathrm{Ca}^{2+}\right]_{\mathrm{i}}$ responses induced by $1 \mathrm{~mm}$ menthol were unaffected by exposure to solutions with $\mathrm{pH}_{\mathrm{o}}$ values as low as 5.4 (Fig. 2C). To ensure that an inhibitory action of protons against menthol was not overlooked when using a single high concentration of agonist, we constructed concentration-response curves with menthol and icilin in solutions of different $\mathrm{pH}$ (Fig. $3 A, B$ ). Acidification of the extracellular solution to $\mathrm{pH} 6.9$ significantly inhibited $\left[\mathrm{Ca}^{2+}\right]_{\mathrm{i}}$ responses to icilin compared with $\mathrm{pH} 7.3$ and shifted the agonist concentration-response curve from a $\mathrm{pEC}_{50}$ value of $7.2 \pm 0.1$ at $\mathrm{pH} 7.3$ to a $\mathrm{pEC}_{50}$ decreased further, the icilin concentration-response curves were shifted even further to the right, and the maximal responses were depressed (Fig. 3A). As in the experiments using only a single the maximal response induced by menthol were significantly affected by acidification of the extracellular solution down to $\mathrm{pH}$ (Fig. 3B)

merature threshold can be modulated by the presence of menthol (McKemy et al., 2002; Peier et al., 2002; Reid et al., 2002) and by icilin (Fig. $3 \mathrm{C}$ ). Superfusing cells at $37^{\circ} \mathrm{C}$ for $1 \mathrm{~min}$ with a subactivating concentration (at this temperature) of icilin (100 nM) or menthol $(25 \mu \mathrm{M})$ before starting a cold ramp caused a leftward shift of the temperature-response curve and elevated the threshold for temperature activation from $22.4 \pm 0.6^{\circ} \mathrm{C}$ in the absence of agonist $(n=4)$ to $26.3 \pm 1.4^{\circ} \mathrm{C}(100 \mathrm{nM}$ icilin; $n=5)$ and $32 \pm 0.9^{\circ} \mathrm{C}(25 \mu \mathrm{M}$ menthol; $n=4)$. When the same experiments were performed in an external solution of pH 6, no $\left[\mathrm{Ca}^{2+}\right]_{\mathrm{i}}$ responses developed with either agonist, indicating that low $\mathrm{pH}$ abolished the synergy between cold and the two agonists $(n=4)$ (Fig. $3 C)$.

\section{pH affects TRPM8 at an \\ intracellular site}

In all the $\left[\mathrm{Ca}^{2+}\right]_{\mathrm{i}}$ measurements described here, the cells studied were equilibrated in test solutions of different $\mathrm{pH}$ for $2-5 \mathrm{~min}$ before stimulation. To discern whether protons were affecting TRPM8 by acting at a target exposed to the extracellular or in- 

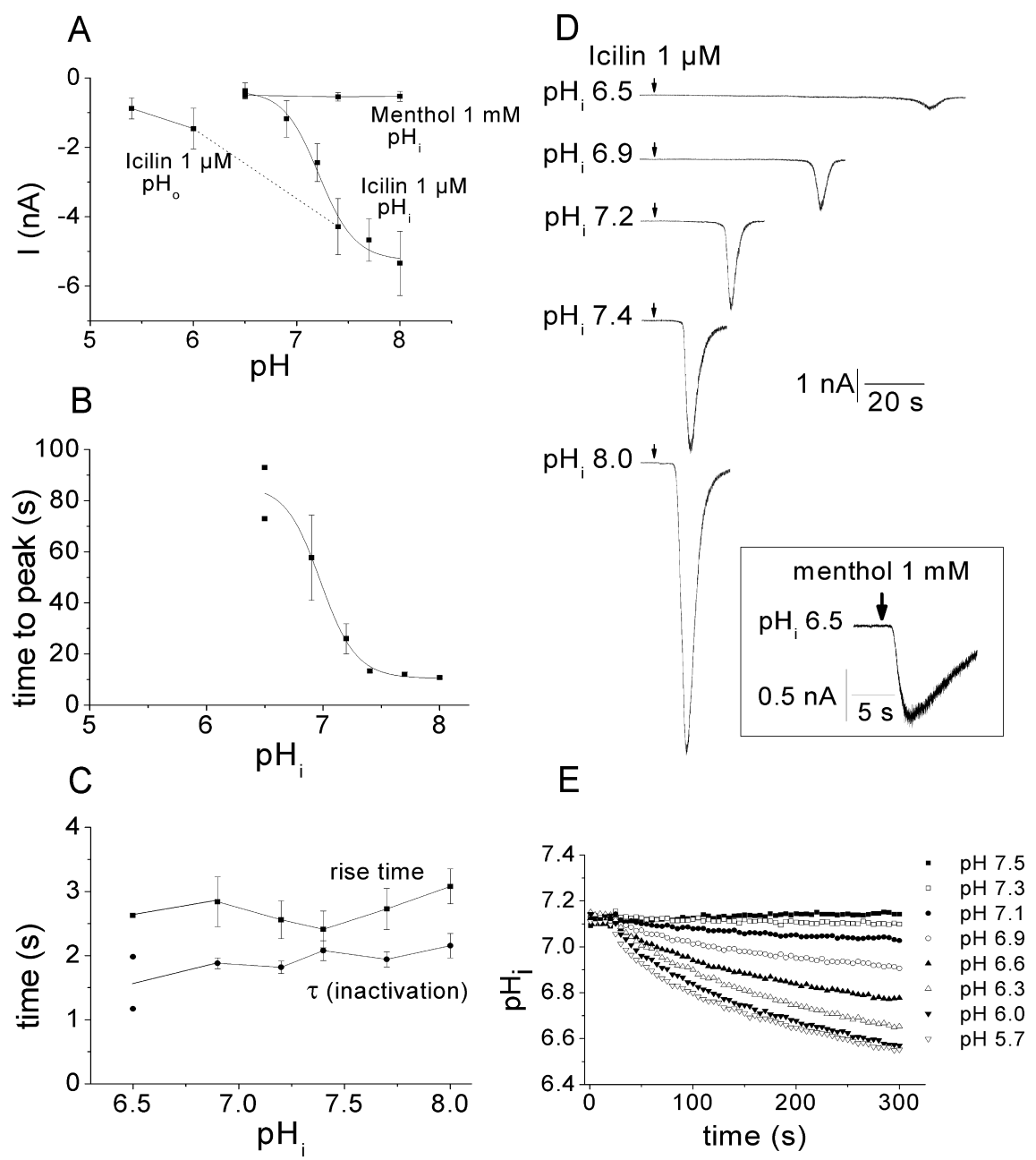

Figure 4. pH modulates TRPM8 activation at an intracellular site. $A$, Although icilin could still evoke inward currents after a 2 min exposure to $\mathrm{pH}_{0} 5.4$, intracellular acidification reduced the current amplitude evoked by $1 \mu \mathrm{m}$ icilin with an estimated half-maximal inhibition of pH7.2 $(n=5-9)$. Inward currents evoked by $1 \mathrm{~mm}$ menthol were smaller than currents evoked by $1 \mu \mathrm{m}$ icilin and not affected by intracellular $\mathrm{pH}(n=12-16)$. B, The latency before icilin-evoked currents developed was increased by intracellular acidification. Data points are averages of cells responding within $120 \mathrm{sec}\left(n=5-9\right.$ cells, except for $\mathrm{pH}_{i} 6.5$, where the only two responding cells are included individually); three of five cells recorded at $\mathrm{pH}_{\mathrm{i}} 6.5$ and two of seven cells recorded at $\mathrm{pH}_{\mathrm{i}} 6.9$ failed to respond during $120 \mathrm{sec}$. C, Intracellular acidification did not affect the time course of icilin-evoked currents. The rise time (time from 10 to $90 \%$ of current developed) and the $\tau$ (inactivation) was similar at all $\mathrm{pH}_{\mathrm{i}}$ tested. Because only two cells responded at $\mathrm{pH}_{\mathrm{i}} 6.5$, the individual data points are shown $\left(n=5-9\right.$ for the other $\mathrm{pH}_{\mathrm{i}}$ values). $D$, Representative recordings illustrating how $\mathrm{pH}_{\mathrm{i}}$ affects icilin-evoked currents. As shown in $A$ and $B$, the current amplitude is depressed and the latency is increased by intracellular acidification. The box demonstrates that inward currents evoked by menthol were unaffected by $\mathrm{pH}_{\mathrm{i}} 6.5$ (compare with Fig. $1 E$ ). E, Extracellular acidification reduced the $\mathrm{pH}_{\mathrm{i}}$ in a time- and $\mathrm{pH}$-dependent manner. Cells were incubated in $\mathrm{pH}_{0} 7.3$ (weakly buffered with $1 \mathrm{~mm}$ HEPES). After $22 \mathrm{sec}$, the $\mathrm{pH}_{0}$ was changed from 7.3 to the indicated values by adding a three times larger volume of strongly buffered solution (10 mм HEPES or MES). Error bars have been omitted for clarity.

tracellular environment, we examined the effect of changing either the external or internal $\mathrm{pH}$ on responses to $1 \mu \mathrm{M}$ icilin in voltage-clamp experiments (Fig. 4). Changing the $\mathrm{pH}$ of the extracellular solutions from $\mathrm{pH} 7.4$ to $\mathrm{pH} 6$ or $\mathrm{pH} 5.4$ reduced the response amplitude from $-4.3 \pm 0.8 \mathrm{nA}$ to $-1.5 \pm 0.6 \mathrm{nA}$ and $-0.9 \pm 0.3 \mathrm{nA}$, respectively (Fig. $4 \mathrm{~A}$ ). When the $\mathrm{pH}_{\mathrm{i}}$ was altered by using different $\mathrm{pH}$ solutions in the recording pipettes, the currents induced by icilin were clearly more sensitive to variations in $\mathrm{pH}_{\mathrm{i}}$ than extracellular $\mathrm{pH}$ (Fig. $4 \mathrm{~A}$ ). Once again, the currents in response to $1 \mu \mathrm{M}$ icilin were larger at higher $\mathrm{pH}_{\mathrm{i}}$ values and smaller at lower $\mathrm{pH}_{\mathrm{i}}$, with an estimated titration midpoint for current size of $\mathrm{pH} 7.2$, which is a value very near the $\mathrm{pH}_{\mathrm{i}}$ in physiological situations. The Hill slope for the inhibitory action of protons was 2.5 , consistent with an action at several sites with a cooperative inhibitory effect. The short lag phase observed previously (Fig. 1D) for icilin-evoked currents in $\mathrm{pH}_{\mathrm{o}} 7.4$ solutions was dependent on $\mathrm{pH}_{\mathrm{i}}$ (Fig. $4 B, D$ ). The latency progressively increased with increasing acidification from $\sim 10 \mathrm{sec}$ in the normal intracellular solution ( $\mathrm{pH} 7.4)$ until only two of five cells tested at $\mathrm{pH}_{\mathrm{i}} 6.5$ responded within $120 \mathrm{sec}$ (Fig. 4B). Unlike the latency, the time course of the currents did not appear to be affected by $\mathrm{pH}_{\mathrm{i}}$ (Fig. $4 C)$. The current rise time, the time taken for currents to grow from 10 to $90 \%$ of the response, was similar at all $\mathrm{pH}_{\mathrm{i}}$ values $(\sim 2.5-3$ sec; $p>0.05$; ANOVA), and the current inactivation, which could be fitted by a single exponential function, occurred with a similar time course ( $\tau$ close to $2 \mathrm{sec}$; $p>0.05$; ANOVA). Consistent with the previous experiments monitoring $\left[\mathrm{Ca}^{2+}\right]_{\mathrm{i}}$ levels, current responses to $1 \mathrm{~mm}$ menthol were not significantly inhibited by $\mathrm{pH}_{\mathrm{i}} 6.5$ or potentiated by $\mathrm{pH}_{\mathrm{i}} 8$ (Fig. $4 \mathrm{~A}$ ) and also developed without the latency observed with icilin.

In light of the effects of $\mathrm{pH}_{\mathrm{i}}$, we were interested in how incubation of cells in extracellular solutions of different $\mathrm{pH}$ affected $\mathrm{pH}_{\mathrm{i}}$. We examined this using the $\mathrm{pH}$-sensitive dye BCECF in a 96-well assay format (Fig. $4 E$ ). The $\mathrm{pH}_{\mathrm{i}}$ was monitored for $5 \mathrm{~min}$, and the $\mathrm{pH}_{\mathrm{o}}$ was changed $20 \mathrm{sec}$ after starting the recording. The resting $\mathrm{pH}_{\mathrm{i}}$ of $\mathrm{CHO}$ cells was $7.12 \pm 0.01$ in an external solution of $\mathrm{pH} 7.3$ at $24^{\circ} \mathrm{C}$. Reducing the $\mathrm{pH}$ of the external solution below 7.3 evoked a time- and $\mathrm{pH}_{\mathrm{o}}$-dependent intracellular acidification such that $\mathrm{pH}_{\mathrm{i}}$ was reduced to $\mathrm{pH} 6.8$ or below $2-5$ min after changing to external solutions of $\mathrm{pH}$ 5.76.0 (Fig. $4 E$ ).

\section{The threshold for cold activation is modulated by $\mathrm{pH}$}

Because responses to cold stimulation $\left(17^{\circ} \mathrm{C}\right)$ (Fig. $\left.2 \mathrm{D}\right)$ and the potentiating effect of cooling on responses to low concentrations of menthol and icilin (Fig. 3C) were inhibited by low $\mathrm{pH}$, we investigated whether $\mathrm{pH}$ modulated the threshold for temperature activation (Fig. 5). Groups of individual cells were exposed to a temperature ramp (from 37 to $\sim 12^{\circ} \mathrm{C}$ ) in solutions of different $\mathrm{pH}_{\mathrm{o}}$. Thresholds were determined by plotting logarithmic values of the change in emission intensity ratios, $\log (\Delta \mathrm{R})$, against temperature (Fig. 5A, inset). Two lines were fitted to these plots, one before and one after the cold-evoked $\left[\mathrm{Ca}^{2+}\right]_{\mathrm{i}}$ responses developed, and the intersection of these lines was regarded as the temperature threshold. At physiological pH 7.3, the threshold for coldinduced $\left[\mathrm{Ca}^{2+}\right]_{\mathrm{i}}$ responses determined in this way was $22.6 \pm$ $0.7^{\circ} \mathrm{C}$, but in more acidic solution the temperature threshold was shifted to progressively lower values (Fig. $5 A$ ). Interestingly, alkaline conditions elevated the activation threshold. In solutions of $\mathrm{pH}$ 8.1, $\left[\mathrm{Ca}^{2+}\right]_{\mathrm{i}}$ responses developed with a threshold of 
$27.6 \pm 1.7^{\circ} \mathrm{C}$. Alkaline solutions thus potentiated $\left[\mathrm{Ca}^{2+}\right]_{\mathrm{i}}$ responses evoked by cold (Fig. 5A). Given the rather strong difference in sensitivity to $\mathrm{pH}_{\mathrm{i}}$ and $\mathrm{pH}_{\mathrm{o}}$ observed with icilin, we next examined the effect of $\mathrm{pH}_{\mathrm{i}}$ on inward currents induced by cold (Fig. $5 B, C$ ). Cells exposed to a cooling ramp from 37 to $\sim 8^{\circ} \mathrm{C}$ (holding potential, $-60 \mathrm{mV}$ ) had an activation threshold of $16.6 \pm 0.5^{\circ} \mathrm{C}$ when the intracellular solution was buffered to $\mathrm{pH} 7.4$ (Fig. $5 B$ ). As observed in the $\left[\mathrm{Ca}^{2+}\right]_{\mathrm{i}}$ experiments, the activation threshold was elevated by more alkaline conditions and depressed by intracellular acidification (Fig. 5A). However, unlike the essentially linear relationship between $\mathrm{pH}_{\mathrm{o}}$ and the cold-evoked $\left[\mathrm{Ca}^{2+}\right]_{\mathrm{i}}$ responses, the $\mathrm{pH}_{\mathrm{i}}$ current curve determined electrophysiologically had a sigmoidal shape with an estimated half-maximal inhibition at $\mathrm{pH} 7.6$ and a slope factor of 1.9. When $\mathrm{pH}_{\mathrm{i}}$ was reduced below 6.7, the inhibitory effect was dramatically increased. Only one of seven cells studied at $\mathrm{pH}_{\mathrm{i}} 6.5$ responded with a threshold above $8^{\circ} \mathrm{C}$. Intracellular $\mathrm{pH}$ also appeared to modify the temperature dependence of the currents once they had started to develop, increasing the rate at higher $\mathrm{pH}_{\mathrm{i}}$ values and slowing the rate at acidic $\mathrm{pH}_{\mathrm{i}}$ (Fig. $5 \mathrm{C}$ ).

\section{Discussion}

TRPM8 has been characterized as a nonselective cation channel activated by low temperature and the two exogenous ligands menthol and icilin (McKemy et al., 2002; Peier et al., 2002). Here, we demonstrate that TRPM8 activity is also strongly modulated by $\mathrm{pH}$. Low $\mathrm{pH}_{\mathrm{o}}(<6.0)$ abolished responses to a strong temperature stimuli completely, and varying the $\mathrm{pH}_{\mathrm{o}}$ from 6.5 to 8.1 shifted the temperature threshold for cold responses from $\sim 15$ to $\sim 27^{\circ} \mathrm{C}$. Icilin and cold responses were inhibited by intracellular acidification and potentiated by intracellular alkalinization. In voltage-clamp recordings in which the $\mathrm{pH}_{\mathrm{i}}$ can be readily controlled, protons reduced the current size in response to icilin with a half-maximal effect at $\mathrm{pH}_{\mathrm{i}} 7.2$, the textbook value for $\mathrm{pH}_{\mathrm{i}}$ under physiological conditions (Fig. $4 A$ ). The threshold for cold activation was shifted to lower temperatures with a half-maximal inhibition at $\mathrm{pH}_{\mathrm{i}} 7.6$ (Fig. $5 B$ ). This modulating effect of $\mathrm{pH}_{\mathrm{i}}$ on responses to icilin and cold exhibited cooperativity, underlining the observation that small changes in $\mathrm{pH}_{\mathrm{i}}$ produce a considerable increase or decrease in the activity of TRPM8. For example, icilin responses were almost fourfold larger at $\mathrm{pH} 7.4$ than at $\mathrm{pH} 6.9$ (Fig. 4A,D). When $\mathrm{pH}_{\mathrm{i}}$ was reduced below $\mathrm{pH}$ 6.5, cold no longer evoked currents in most cells, even in cells that were cooled to $8^{\circ} \mathrm{C}$. Similarly, icilin often failed to produce a current during a 2 min application in cells tested at $\mathrm{pH}_{\mathrm{i}} 6.5$. Thus, the $\mathrm{pH}$ inhibition seems to increase sharply at approximately $\mathrm{pH}_{\mathrm{i}} 6.5$. Because it is unlikely that $\mathrm{pH}_{\mathrm{i}}$ changes will significantly affect even the local $\mathrm{pH}_{\mathrm{o}}$ around cells subjected to superfusion, the observed $\mathrm{pH}$ modulation must be mostly explained by an intracellular action. This is unlike the effect of $\mathrm{pH}$ on TRPV1 that has been shown to involve negatively charged residues in or near the pore-forming loop exposed to the extracellular environment (Garcia-Martinez et al., 2000; Jordt et al., 2000). Experiments in which we monitored the $\mathrm{pH}_{\mathrm{i}}$ using the $\mathrm{pH}$-sensitive dye BCECF illustrate that extracellular acidification decreases $\mathrm{pH}_{\mathrm{i}}$. However, this change is time dependent, and the $\mathrm{pH}_{\mathrm{i}}$ does not equilibrate with $\mathrm{pH}_{\mathrm{o}}$ in $\mathrm{CHO}$ cells within the time scale of our experiments. This finding explains the difference in $\mathrm{pH}$ sensitivity between the experiments with Fura-2, in which $\mathrm{pH}_{\mathrm{o}}$ was altered and $\mathrm{pH}_{\mathrm{i}}$ was not controlled $\left(\mathrm{pIC}_{50}\right.$ values of 6.3 for cold and icilin), and the voltage-clamp experiments, in which $\mathrm{pH}_{\mathrm{i}}$ was buffered directly $\left(\mathrm{pIC}_{50}\right.$ values of 7.6 and 7.2 for cold and icilin). It is also a probable explanation for the apparently linear rather than sigmoidal dependence of temperature threshold on $\mathrm{pH}_{\mathrm{o}}$ observed in Figure $5 \mathrm{~A}$.

In contrast to our findings with icilin and cold, menthol was entirely resistant to the effects of $\mathrm{pH}_{\mathrm{o}}$ as well as $\mathrm{pH}_{\mathrm{i}}$. Thus, the concentration-response relationship for menthol was unaffected by conditions under which icilin could no longer activate TRPM8 (Fig. 3A,B). In comparison, Behrendt et al. (2004) recently showed that $\left[\mathrm{Ca}^{2+}\right]_{\mathrm{i}}$ responses to single concentrations of menthol and icilin were reduced by incubation in solutions of $\mathrm{pH} 6.8$ and $\mathrm{pH} 6.3$ (although responses to menthol were less sensitive than were those to icilin). Another difference in the responses to the two agonists was that although the responses to menthol developed rapidly without any obvious latency, responses to icilin occurred after a delay. This initial delay or lag phase was strongly increased by low $\mathrm{pH}_{\mathrm{i}}$ (Fig. $4 B, D$ ). With menthol, we never observed a lag phase, even at the lowest $\mathrm{pH}$ value tested $\left(\mathrm{pH}_{\mathrm{i}}\right.$ 6.5). Curiously, after the lag phase, the response to icilin itself developed rapidly. A striking finding was that the time course of the current responses to icilin were not affected by $\mathrm{pH}_{\mathrm{i}}$, although the latency and amplitude were markedly altered. This suggest that the icilin-evoked responses are triggered in an all-ornone-type manner. However, the observation that low $\mathrm{pH}_{\mathrm{i}}$ extends the time required to reach such a trigger or threshold does not help to clarify why the current size is simultaneously reduced and suggests that these two phenomena may be separate effects of acidification. Together, the pronounced differences in the properties of the responses evoked by menthol and icilin are hard to reconcile with the notion of them acting as agonists through a similar mechanism. Both compounds are stable in the $\mathrm{pH}$ range used in this study, so our data cannot be explained by a direct effect of $\mathrm{pH}$ on either of the compounds. However, the results would be consistent with icilin responses being dependent on a $\mathrm{pH}$-sensitive intracellular metabolic event or pathway that menthol is not. Because cold responses are also sensitive to $\mathrm{pH}_{\mathrm{i}}$, it can further be speculated that differences in this putative mechanism can explain why the threshold for temperature activation observed here in $\mathrm{CHO}$ cells was considerably lower than in cultured neurons from trigeminal $\left(27^{\circ} \mathrm{C}\right)$ (McKemy et al., 2002) and 
DRGs $\left(\sim 28^{\circ} \mathrm{C}\right)$ (Reid et al., 2002). The temperature-current relationship for cold-activated currents was very steep. Furthermore, the temperature dependence was reduced by intracellular acidification (Fig. 5C). Analysis of the recording performed at $\mathrm{pH}_{\mathrm{i}} 6.7$ (Fig. 5C) produced an apparent Q10 of 40, but much greater values were consistently seen for recordings performed at higher $\mathrm{pH}_{\mathrm{i}}$. Such high temperature dependence is hard to reconcile with a direct effect on the channel but would be consistent with an indirect effect acting via a cascade system or another form of amplification.

The temperature threshold for cold activation was strongly elevated by the presence of a subactivating concentration of menthol or icilin (concentrations that did not evoke responses on their own at $37^{\circ} \mathrm{C}$ ). At low $\mathrm{pH}$ these synergistic effects on activation were not seen because cooling failed to elicit responses in the presence of either agonist (Fig. 3C). Because menthol responses are $\mathrm{pH}$ insensitive (Fig. $3 B$ ), this effect must be on cold activation, which fails to operate under acidic conditions even in the presence of menthol. The threshold for cold activation was considerably lower in the voltage-clamp experiments than in the $\left[\mathrm{Ca}^{2+}\right]_{\mathrm{i}}$ measurements (Fig. $5 A, B$ ). Although the reason for this is not known to us, it seems likely that this lower sensitivity to cold can be explained by the assay conditions in voltage-clamp measurements, such as the membrane potential or dialysis of the cellular contents by the pipette solution.

Alkalosis (metabolic alkalosis and hypocapnic alkalosis) are common clinical manifestations of many different etiologies (Galla, 2000; Laffey and Kavanagh, 2002). It has long been known that alkalosis increases the excitability of central and DRG neurons (that may lead to cramps and seizures among other symptoms) and increases the activity of voltage-operated calcium channels (Somjen and Tombaugh, 1998; Tombaugh and Somjen, 1998). Intracellular alkalinization strongly increases the affinity of Ins $(1,4,5,) \mathrm{P}_{3}$ for Ins $(1,4,5,) \mathrm{P}_{3}$ receptors (Worley et al., 1987) and increases the release of $\mathrm{Ca}^{2+}$ through $\operatorname{Ins}(1,4,5,) \mathrm{P}_{3}$ receptors as well as ryanodine receptors (Joseph et al., 1989; Heppner et al., 2002). Recently, experiments with vascular smooth muscle cells have shown that raising $\mathrm{pH}_{\mathrm{i}}$ activates a nonselective calcium-permeable cation channel with properties resembling those of many TRP channels, but of unknown identity (Poteser et al., 2003). Thus, different pathways that can activate or potentiate TRP or TRP-like channels and lead to increased $\left[\mathrm{Ca}^{2+}\right]_{\mathrm{i}}$ share a common potentiation by elevated $\mathrm{pH}_{\mathrm{i}}$.

We found that not only menthol, but also icilin and intracellular alkalinization, elevate the temperature threshold for cold activation of TRPM8. TRPV1 is often referred to as a polymodal molecular sensor because its activity is regulated by stimuli of different modalities. Heat, low $\mathrm{pH}$, and chemical ligands can all gate TRPV1 and also potentiate the effect of each other (Tominaga et al., 1998). By similar criteria, TRPM8 would qualify as a polymodal molecular sensor, sensing temperature, $\mathrm{pH}$, and "cooling compounds."

Although it remains to be shown whether the $\mathrm{pH}$ effect observed here affects TRPM8 in vivo, the $\mathrm{pIC}_{50}$ values of 7.2 and 7.6 against icilin and cold are close to the $\mathrm{pH}_{\mathrm{i}}$ under physiological conditions, indicating that small changes in $\mathrm{pH}_{\mathrm{i}}$ can affect cold perception by regulating the excitability of TRPM8-expressing cold fibers. The inhibitory effect of protons applied intracellularly showed a steep concentration dependence, consistent with an action at more than one site. As yet, it is unclear to us whether these sites are intrinsic to the channel protein or not, but the fact that menthol is resistant to the modulating effects of $\mathrm{pH}$ implies that TRPM8 can be activated by at least two distinct mechanisms.

\section{References}

Behrendt HJ, Germann T, Gillen C, Hatt H, Jostock R (2004) Characterization of the mouse cold-menthol receptor TRPM8 and vanilloid receptor type-1 VR1 using a fluorometric imaging plate reader (FLIPR) assay. Br J Pharmacol 141:737-745.

Galla JH (2000) Metabolic alkalosis. J Am Soc Nephrol 11:369-375.

Garcia-Martinez C, Morenilla-Palao C, Planells-Cases R, Merino JM, FerrerMontiel A (2000) Identification of an aspartic residue in the P-loop of the vanilloid receptor that modulates pore properties. J Biol Chem 275:32552-32558.

Heppner TJ, Bonev AD, Santana LF, Nelson MT (2002) Alkaline pH shifts $\mathrm{Ca} 2+$ sparks to $\mathrm{Ca} 2+$ waves in smooth muscle cells of pressurized cerebral arteries. Am J Physiol Heart Circ Physiol 283:H2169-H2176.

Jordt SE, Tominaga M, Julius D (2000) Acid potentiation of the capsaicin receptor determined by a key extracellular site. Proc Natl Acad Sci USA 97:8134-8139.

Joseph SK, Rice HL, Williamson JR (1989) The effect of external calcium and $\mathrm{pH}$ on inositol trisphosphate-mediated calcium release from cerebellum microsomal fractions. Biochem J 258:261-265.

Klement W, Arndt JO (1992) The role of nociceptors of cutaneous veins in the mediation of cold pain in man. J Physiol 449:73-83.

Kress M, Fetzer S, Reeh PW, Vyklicky L (1996) Low pH facilitates capsaicin responses in isolated sensory neurons of the rat. Neurosci Lett 211:5-8.

Laffey JG, Kavanagh BP (2002) Hypocapnia. N Engl J Med 347:43-53.

Maingret F, Lauritzen I, Patel AJ, Heurteaux C, Reyes R, Lesage F, Lazdunski M, Honore E (2000) TREK-1 is a heat-activated background $\mathrm{K}(+)$ channel. EMBO J 19:2483-2491.

McKemy DD, Neuhausser WM, Julius D (2002) Identification of a cold receptor reveals a general role for TRP channels in thermosensation. $\mathrm{Na}-$ ture 416:52-58.

McLatchie LM, Bevan S (2001) The effects of $\mathrm{pH}$ on the interaction between capsaicin and the vanilloid receptor in rat dorsal root ganglia neurons. $\mathrm{Br} \mathrm{J}$ Pharmacol 132:899-908.

Nealen ML, Gold MS, Thut PD, Caterina MJ (2003) TRPM8 mRNA is expressed in a subset of cold-responsive trigeminal neurons from rat. J Neurophysiol 90:515-520.

Peier AM, Moqrich A, Hergarden AC, Reeve AJ, Andersson DA, Story GM, Earley TJ, Dragoni I, McIntyre P, Bevan S, Patapoutian A (2002) A TRP channel that senses cold stimuli and menthol. Cell 108:705-715.

Poteser M, Wakabayashi I, Rosker C, Teubl M, Schindl R, Soldatov NM, Romanin C, Groschner K (2003) Crosstalk between voltageindependent $\mathrm{Ca} 2+$ channels and L-type Ca2 + channels in $\mathrm{A} 7 \mathrm{r} 5$ vascular smooth muscle cells at elevated intracellular $\mathrm{pH}$ : evidence for functional coupling between L-type Ca2 + channels and a 2-APB-sensitive cation channel. Circ Res 92:888-896.

Reid G, Babes A, Pluteanu F (2002) A cold- and menthol-activated current in rat dorsal root ganglion neurones: properties and role in cold transduction. J Physiol (Lond) 545:595-614.

Savidge JR, Ranasinghe SP, Rang HP (2001) Comparison of intracellular calcium signals evoked by heat and capsaicin in cultured rat dorsal root ganglion neurons and in a cell line expressing the rat vanilloid receptor, VR1. Neuroscience 102:177-184.

Somjen GG, Tombaugh GC (1998) pH modulation of neuronal excitability and central nervous system functions. In: $\mathrm{pH}$ and brain function (Kaila K, Ransom BR, eds), pp 373-394. New York: Wiley.

Story GM, Peier AM, Reeve AJ, Eid SR, Mosbacher J, Hricik TR, Earley TJ, Hergarden AC, Andersson DA, Hwang SW, McIntyre P, Jegla T, Bevan S, Patapoutian A (2003) ANKTM1, a TRP-like channel expressed in nociceptive neurons, is activated by cold temperatures. Cell 112:819-829.

Tombaugh GC, Somjen GG (1998) pH modulation of voltage-gated ion channels. In: pH and brain function (Kaila K, Ransom BR, eds), pp 395416. New York: Wiley.

Tominaga M, Caterina MJ, Malmberg AB, Rosen TA, Gilbert H, Skinner K, Raumann BE, Basbaum AI, Julius D (1998) The cloned capsaicin receptor integrates multiple pain-producing stimuli. Neuron 21:531-543.

Tsavaler L, Shapero MH, Morkowski S, Laus R (2001) Trp-p8, a novel prostate-specific gene, is up-regulated in prostate cancer and other malignancies and shares high homology with transient receptor potential calcium channel proteins. Cancer Res 61:3760-3769.

Worley PF, Baraban JM, Supattapone S, Wilson VS, Snyder SH (1987) Characterization of inositol trisphosphate receptor binding in brain. Regulation by pH and calcium. J Biol Chem 262:12132-12136. 